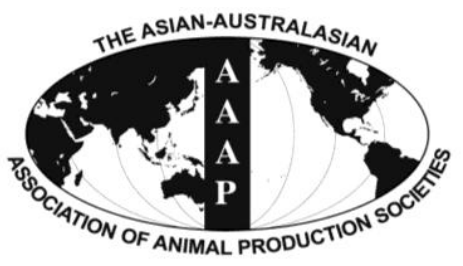

Open Access

Asian Australas. J. Anim. Sci.

Vol. 27, No. 10 : 1478-1486 October 2014

http://dx.doi.org/10.5713/ajas.2014.14038

www.ajas.info

pISSN 1011-2367 elSSN 1976-5517

\title{
Evaluation of the Efficacy of Fermented By-product of Mushroom, Pleurotus ostreatus, as a Fish Meal Replacer in Juvenile Amur Catfish, Silurus asotus: Effects on Growth, Serological Characteristics and Immune Responses
}

\author{
Kumar Katya, Yong-hyun Yun, Gunhyun Park, Jeong-Yeol Lee', Gwangyeol Yoo², and Sungchul C. Bai* \\ Department of Marine Bio-materials and Aquaculture / Feeds and Foods Nutritional Research Center, \\ Pukyong National University, Busan 608-737, Korea
}

\begin{abstract}
The present experiment was conducted to evaluate the efficacy of dietary fermented by-product of mushroom, Pleurotus ostreatus, (FBPM) as a fish meal (FM) replacer in juvenile Amur catfish, Silurus asotus. A total number of 225 fish averaging $5.7 \pm 0.1 \mathrm{~g}$ (mean \pm standard deviation) were fed one of the five experimental diets formulated to replace FM with FBPM at $0 \%, 5 \%, 10 \%, 20 \%$, and $30 \%\left(\mathrm{FBPM}_{0}, \mathrm{FBPM}_{5}, \mathrm{FBPM}_{10}, \mathrm{FBPM}_{20}\right.$, and $\mathrm{FBPM}_{30}$, respectively). At the end of eight weeks of the experiment, average weight gain (WG) of fish fed $\mathrm{FBPM}_{0}$ or $\mathrm{FBPM}_{5}$ were significantly higher than those of fish fed $\mathrm{FBPM}_{20}$ or $\mathrm{FBPM}_{30}$ diets $(\mathrm{p}<0.05$ ). However, there was no significant differences in WG among the fish fed $\mathrm{FBPM}_{0}, \mathrm{FBPM}_{5}$ or $\mathrm{FBPM}_{10}$, and between fish fed $\mathrm{FBPM}_{10}$ or FBPM $\mathrm{F}_{20}$, and also between those fed $\mathrm{FBPM}_{20}$ or $\mathrm{FBPM}_{30}$ diets. Lysozyme activity of fish fed $\mathrm{FBPM}_{0}$ or $\mathrm{FBPM}_{5}$ were significantly higher than those of fish fed $\mathrm{FBPM}_{10}, \mathrm{FBPM}_{20}$ or $\mathrm{FBPM}_{30}$ diets $(\mathrm{p}<0.05)$. The chemiluminescent response of fish fed $\mathrm{FBPM}_{5}$ was significantly higher than those of fish fed $\mathrm{FBPM}_{0}, \mathrm{FBPM}_{20}$ or $\mathrm{FBPM}_{30}$ diets $(\mathrm{p}<0.05)$. Broken line regression analysis of WG suggested that the maximal dietary inclusion level for FBPM as a FM replacer could be $6.3 \%$ without any adverse effects on whole body composition and on serological characteristics. Therefore, these results may indicate that the maximal dietary inclusion level of FBPM as a FM replacer could be $6.3 \%$ in juvenile Amur catfish. (Key Words: Fermented Mushroom, Fish Meal Replacer, Juvenile Amur Catfish, Growth, Immune Response)
\end{abstract}

\section{INTRODUCTION}

Aquaculture is a rapidly growing food-producing industry; however, there is still considerable potential for increased efficiency and efficacy of aquaculture through development of nutritious and cost-effective alternatives to traditional marine protein feedstuffs such as fish meal (FM) (Suarez et al., 2013). The FM cost 500 US dollars per metric ton in the middle of 90s but nowadays its cost has quadrupled (World Bank Commodity, 2010). Lee and Bai

\footnotetext{
* Corresponding Author: Sungchul C. Bai. Tel: +82-51-6297922, Fax: +82-51-6286873, E-mail: scbai@pknu.ac.kr

${ }^{1}$ Department of Aquaculture and Aquatic Science, Kunsan Nat'1 University, Gunsan 573-701, Korea.

2 The Province of Chungcheongnam-do Fisheries Research Institute, Boryeong 355-880, Korea.

Submitted Jan. 16, 2014; Revised Apr. 22, 2014; Accepted May 8, 2014
}

(1997a) noted that the world supply of FM increased only about $27 \%$ in 20 years and FM output by the major FM producing countries actually declined. Because of the limiting supply of FM around the world, the cost of producing fish is expected to continue to increase. Consequently, many studies have been conducted to replace FM or to reduce its inclusion in fish diets by various less expensive alternative protein sources. Some of the readily available ingredients studied with the view of using them to partially replace FM in fish feed include plant protein sources such as soybean meal, corn gluten meal and soy protein concentrate (Carter and Hauler, 2000; Refstie et al., 2001; Choi et al., 2004; Lim et al., 2004; Kim et al., 2008) and animal protein sources such as meat and bone meal, blood meal, feather meal, poultry by-product meal (PBM) and lysine by-product (Bai et al., 1997,1998; Lee and Bai, 1997a,b).

Copyright (? 2014 by Asian-Australasian Journal of Animal Sciences This is an open-access article distributed under the terms of the Creative Commons Attribution Non-Commercial License (http://creativecommons.org/licenses/by-nc/3.0/), which permits unrestricted non-commercial use, distribution, and reproduction in any medium, provided the original work is properly cited. 
Pleurotus ostreatus is one of the most important mushroom species in Korea and the world. Worldwide production of this species has greatly increased during the previous few decades (Chang, 1999; Royse, 2002). The increase in popularity of this species is attributed to its ease of cultivation, high yield potential, high nutritional value, medicinal properties and other beneficial effects (Banik and Nandi, 2004). Pleurotus ostreatus, along with other species of mushroom, has been confirmed to have medicinal value. The biological functionality of these mushrooms ranges from antioxidative and immuno-stimulating to antiviral, anti-carcinogenic, antihypercholesterolaemic, and the ability to regulate blood lipid and glucose levels (Gordon et al., 1998; Wasser and Weis, 1999; Lakhanpal and Rana, 2005). The bioactive compounds in these species have been identified as oligosaccharides, polysaccharides, dietary fibers, glycoproteins, proteins, peptides, amino acids, triterpenoids, alkaloids, alcohols, phenols, polyphenols, vitamins, and/or minerals such as zinc, copper, iodine, selenium and iron. Pleurotus ostreatus contains high levels of glucans, which are polymers of glucose found in the cell walls of plants, fungi and bacteria (Sonck et al., 2010; Kim et al., 2011). It has been reported that $\beta$-glucans have the capacity to activate innate immunity, thereby enhancing defense barriers in animals including fish (Kim et al., 2006; Yoo et al., 2007; Sonck et al., 2010).

Amur catfish, Silurus asotus, is one of the important freshwater aquaculture species in Korea. The aquaculture production of Amur catfish in Korea in 2010 was 4,194 metric tons and this was valued at over ten million US dollars (FAO, 2012). However, using FM in fish feed increases the feed cost and is not a sustainable long-term feeding strategy (Naylor et al., 2009; FAO, 2010) and more work is needed to identify alternative protein-rich ingredients suitable for cultured fish (Kader et al., 2010). However, there are few nutritional studies on Amur catfish. In line with the dearth of knowledge regarding Amur catfish, the effects of dietary fermented by-product of mushroom (FBPM) as a FM replacer has not been investigated. Therefore, the present study was carried out to evaluate the optimum inclusion level of FBPM as a FM replacer in Amur catfish, Silurus asotus.

\section{MATERIALS AND METHODS}

\section{Experimental design and diets}

Formulation and proximate composition of the experimental diets is shown in Table 1. Five experimental

Table 1. Formulation and proximate composition of the experimental diets fed to juvenile Amur catfish (\% of dry matter basis)

\begin{tabular}{|c|c|c|c|c|c|}
\hline \multirow{2}{*}{ Items } & \multicolumn{5}{|c|}{ Diets $^{1}$} \\
\hline & $\mathrm{FBPM}_{0}$ & $\mathrm{FBPM}_{5}$ & $\mathrm{FBPM}_{10}$ & $\mathrm{FBPM}_{20}$ & $\mathrm{FBPM}_{30}$ \\
\hline \multicolumn{6}{|l|}{ Ingredients } \\
\hline Fish meal $^{2}$ & 30 & 28.5 & 27 & 24 & 21 \\
\hline Fermented mushroom by-product ${ }^{3}$ & 0 & 2.2 & 4.4 & 8.7 & 13.1 \\
\hline Soybean meal $^{4}$ & 14.3 & 14.3 & 14.3 & 14.7 & 15.5 \\
\hline Corn gluten meal ${ }^{4}$ & 12.1 & 12.1 & 12.1 & 12.1 & 12.1 \\
\hline Squid liver powder ${ }^{4}$ & 10.0 & 10.0 & 10.0 & 10.0 & 10.0 \\
\hline Meat meal ${ }^{4}$ & 6.5 & 6.5 & 6.5 & 6.5 & 6.5 \\
\hline Wheat flour ${ }^{4}$ & 19.6 & 19.6 & 19.6 & 18.4 & 16.0 \\
\hline Fish oil $^{4}$ & 1.5 & 1.7 & 1.8 & 2.1 & 2.4 \\
\hline Soybean oil ${ }^{4}$ & 1.5 & 1.5 & 1.5 & 1.5 & 1.5 \\
\hline Vitamin premix ${ }^{5}$ & 1.0 & 1.0 & 1.0 & 1.0 & 1.0 \\
\hline Mineral premix ${ }^{6}$ & 1.0 & 1.0 & 1.0 & 1.0 & 1.0 \\
\hline Cellulose ${ }^{4}$ & 2.5 & 1.6 & 0.8 & 0 & 0 \\
\hline \multicolumn{6}{|l|}{ Proximate composition } \\
\hline Moisture & 10.9 & 9.5 & 9.6 & 10.0 & 10.7 \\
\hline Crude protein & 47.5 & 47.4 & 47.6 & 47.5 & 47.1 \\
\hline Crude lipid & 8.9 & 8.9 & 8.9 & 8.9 & 8.9 \\
\hline Crude ash & 10.9 & 10.3 & 10.7 & 10.2 & 10.3 \\
\hline
\end{tabular}

FBPM, fermented mushroom by-product.

${ }^{1} \mathrm{FBPM}_{0}: 100 \%$ fish meal-based diet; $\mathrm{FBPM}_{5}, \mathrm{FBPM}_{10}, \mathrm{FBPM}_{20}, \mathrm{FBPM}_{30}: 5 \%, 10 \%, 20 \%$, and 30\% fish meal protein replaced by $\mathrm{FBPM}$, respectively.

${ }^{2}$ Suhyup Co., Busan, Republic of Korea.

${ }^{3}$ Mushroom Research Institute, Gyeonggi Province, Republic of Korea.

${ }^{4}$ Suhyup Co., Busan, Republic of Korea.

${ }^{5}$ Contains (as $\mathrm{mg} / \mathrm{kg}$ in diets): ascorbic acid, 300; dl-calcium pantothenate, 150; choline bitatrate, 3,000; inositol, 150; menadione, 6; niacin, 150; pyridoxine $\mathrm{HCl}, 15$; riboflavin, 30; thiamine mononitrate, 15 ; dl- $\alpha$-tocopherol acetate, 201 ; retinyl acetate, 6 ; biotin, $1.5 ;$ folic acid, 5.4 ; $\mathrm{B}_{12}, 0.06$.

${ }^{6}$ Contains (as mg/kg in diets): $\mathrm{NaCl}, 437.4 ; \mathrm{MgSO}_{4} \cdot 7 \mathrm{H}_{2} \mathrm{O}, 1,379.8 ; \mathrm{NaH}_{2} \mathrm{P}_{4} \cdot 2 \mathrm{H}_{2} \mathrm{O}, 877.8 ; \mathrm{Ca}\left(\mathrm{H}_{2} \mathrm{PO}_{4}\right)_{2} \cdot 2 \mathrm{H}_{2} \mathrm{O}, 1,366.7 ; \mathrm{KH}_{2} \mathrm{PO}_{4}, 2,414 ; \mathrm{ZnSO}_{4} \cdot 7 \mathrm{H}_{2} \mathrm{O}$, 226.4; Fe-Citrate, 299; Ca-lactate, 3,004; $\mathrm{MnSO}_{4}, 0.016 ; \mathrm{FeSO}_{4}, 0.0378 ; \mathrm{CuSO}_{4}, 0.00033 ;$ Calcium iodate, $0.0006 ; \mathrm{MgO}, 0.00135 ; \mathrm{NaSeO}$, 0.00025 . 
diets were formulated to contain different levels of FBPM to replace $0 \%, 5 \%, 10 \%, 20 \%$, and $30 \%$ of $\mathrm{FM}\left(\mathrm{FBPM}_{0}\right.$, $\mathrm{FBPM}_{5}, \mathrm{FBPM}_{10}, \mathrm{FBPM}_{20}$, and $\mathrm{FBPM}_{30}$, respectively). The five diets were formulated to contain $47 \%$ crude protein and $16.0 \mathrm{~kJ}$ available energy/g. Fishmeal, dehulled soybean meal, corn gluten meal, squid liver powder and meat meal served as the major protein sources in the experimental diets; fish oil and soybean oil were used as lipid sources while wheat flour was the carbohydrate source. Cellulose was included in the diets to adjust the crude protein and energy levels. Mushroom by-product was obtained from Mushroom Research Institute, Gyeonggi Province, Republic of Korea. The mushroom by-product was fermented using a fermentation machine for $24 \mathrm{~h}$ at $30^{\circ} \mathrm{C}$ with lactobacillus and yeast at $3.93 \times 10^{8}$ and $6.56 \times 10^{9}$ $\mathrm{CFU} / \mathrm{g}$, respectively. It contained $42 \%$ crude protein, $0.3 \%$ crude lipid and $8.2 \%$ crude ash on a dry-matter basis. Procedures for diet preparation and storage were as previously described by Bai and Kim (1997). After thoroughly mixing the dry ingredients and fish oil with $30 \%$ filtered tap water, experimental diets were pelleted with a laboratory pelleting machine without heating using a 2-mm diameter module (Baokyong Commercial Co., Busan, Korea). After processing, all diets were kept at $-20^{\circ} \mathrm{C}$ in a freezer until use.

\section{Experimental fish and feeding trial}

Juvenile Amur catfish, Silurus asotus, were obtained from Jeong-eup, Republic of Korea. Fish were transported to the experimental station (Pukyong National University, Busan, Republic of Korea) and acclimated to the experimental conditions for two weeks before the feeding trial began. During the acclimation period, fish were fed $\mathrm{FBPM}_{0}$ diet twice daily (1000 and $\left.1800 \mathrm{~h}\right)$ at approximately $4 \%$ of wet body weight/day. A total number of 225 fish averaging $5.7 \pm 0.1 \mathrm{~g}$ (mean \pm standard deviation $[\mathrm{SD}]$ ) were randomly distributed in fifteen individual fish groups to each of fifteen aquaria. Each aquarium was then randomly assigned to one of three replicates of five experimental diets. Triplicate groups of fish were fed the experimental diets twice daily $(1000$ and $1800 \mathrm{~h})$ at approximately $4 \%$ of wet body weight/d at the beginning and $3 \%$ of wet body weight/d at the end of the feeding trial for eight weeks. Total fish weight in each aquarium was determined every 2 weeks, and the feeding rate was adjusted accordingly.

The feeding trial was conducted in an indoor semirecirculation system with fifteen $40 \mathrm{~L}$ aquaria receiving filtered freshwater from the center tank. Supplemental aeration was provided to maintain dissolved oxygen levels near $6.5 \pm 0.5 \mathrm{ppm}$. Water temperature was $24 \pm 1^{\circ} \mathrm{C}$ $($ mean \pm SD); $\quad \mathrm{pH}$ was $7.5 \pm 0.3 \quad($ mean $\pm \mathrm{SD})$ and the photoperiod was 12:12 (light:dark) during the whole experimental period.

\section{Sample collection and analysis}

At the end of the feeding trial, all of the fish were weighed and counted for calculation of weight gain (WG), specific growth rate (SGR), feed efficiency (FE), protein efficiency ratio (PER), and survival. Three fish per aquarium were randomly selected and dissected to obtain the liver and white muscle samples, and hepatosomatic index (HSI) was calculated. After the final weighing, three fish were randomly collected from each aquarium and frozen at $-20^{\circ} \mathrm{C}$ for analysis. A proximate composition analysis of the experimental diets was performed by the standard methods of AOAC (1995). Samples were dried to a constant weight at $105^{\circ} \mathrm{C}$ to determine moisture content. Ash was determined by incineration at $550^{\circ} \mathrm{C}$, crude lipid by soxhlet extraction using a Soxtec system 1046 (Tecator AB, Hoganas, Sweden), and crude protein by Kjeldahl method $(\mathrm{N} \times 6.25)$ after acid digestion. The same fish as subjected to HSI calculation, were also used to analyze serological characteristics. Blood samples were obtained from the caudal vessels of the fish with $1 \mathrm{~mL}$ syringes. Hematocrit (HCT) was determined on three fish randomly selected per aquarium by the microhematocrit method (Brown, 1980), and hemoglobin (Hb) was measured in the same three fish by the cyan-methemoglobin procedure using Drabkins reagent. An $\mathrm{Hb}$ standard prepared form human blood (Sigma Chemical, St. Louis, Missouri, USA) was used. Serum samples were prepared from blood on clotting by centrifugation at $1,600 \times \mathrm{g}$. for $10 \mathrm{~min}$ and then the samples were stored at $-20^{\circ} \mathrm{C}$ until analyzed. Serum was analyzed using commercial clinical investigation kits (NeoDin Co., Ltd., Seoul, Korea) and the specific method employed as follows: the biuret method for serum total protein and the enzymatic method for Glucose.

\section{Nonspecific immune response assay}

Chemiluminescent response: Head kidneys were aseptically removed from three randomly selected fish from each tank, and pushed through a mesh with cold Hank's balanced salt solution (HBSS) at $4^{\circ} \mathrm{C}$. The suspension of leucocytes was immediately placed on a $34 / 51 \%$ Percoll (Sigma) density gradient and centrifuged at 2,000 rpm for $30 \mathrm{~min}$ at $4^{\circ} \mathrm{C}$. The interphase was collected and the cells were washed twice at 2,000 rpm for $5 \mathrm{~min}$ in Dulbecco's modified Eagle's medium containing heparin $(10 \mathrm{U} / \mathrm{mL}$, Sigma) supplemented with streptomycin $(100 \mathrm{U} / \mathrm{mL}$, Sigma), penicillin G (100 $\mu \mathrm{g} / \mathrm{mL}$, Sigma). The cell viability was examined with trypan blue exclusion and it was evaluated to be greater than $98 \%$. The leucocytes including neutrophils and monocytes were adjusted to $0.5 \times 10^{6}$ cells/mL HBSS. Samples were pre-incubated in 96 well plate each of $200 \mu \mathrm{L}$ for $2 \mathrm{~h}$ at $25^{\circ} \mathrm{C}$. Zymosan $(10 \mathrm{mg} / \mathrm{mL}$, Sigma) was mixed with the serum of adult rockfish, which were not used in this feeding experiment, and incubated at 
Table 2. Growth performance of juvenile Amur catfish, Silurus asotus, fed dietary fermented by-product of mushroom, Pleurotus ostreatus, as a fish meal replacer

\begin{tabular}{|c|c|c|c|c|c|c|}
\hline \multirow{2}{*}{ Items } & \multicolumn{5}{|c|}{ Diets $^{1}$} & \multirow{2}{*}{ Pooled SEM ${ }^{2}$} \\
\hline & $\mathrm{FBPM}_{0}$ & $\mathrm{FBPM}_{5}$ & $\mathrm{FBPM}_{10}$ & $\mathrm{FBPM}_{20}$ & $\mathrm{FBPM}_{30}$ & \\
\hline WG $(\%)^{3}$ & $278.3^{\mathrm{a}}$ & $273.7^{\mathrm{a}}$ & $226.9^{\mathrm{ab}}$ & $201.8^{\mathrm{bc}}$ & $140.4^{\mathrm{c}}$ & 15.6 \\
\hline $\operatorname{SGR}(\% / \mathrm{d})^{4}$ & $2.37^{\mathrm{a}}$ & $2.35^{\mathrm{a}}$ & $2.11^{\mathrm{a}}$ & $1.97^{\mathrm{a}}$ & $1.53^{\mathrm{b}}$ & 0.10 \\
\hline $\mathrm{FE}(\%)^{5}$ & $88.9^{\mathrm{a}}$ & $88.7^{\mathrm{a}}$ & $81.9^{\mathrm{ab}}$ & $80.1^{\mathrm{ab}}$ & $62.1^{\mathrm{b}}$ & 3.8 \\
\hline $\mathrm{PER}^{6}$ & $1.85^{\mathrm{a}}$ & $1.87^{\mathrm{a}}$ & $1.72^{\mathrm{ab}}$ & $1.69^{\mathrm{ab}}$ & $1.32^{\mathrm{b}}$ & 0.08 \\
\hline $\operatorname{HSI}(\%)^{7}$ & $1.77^{\mathrm{ab}}$ & $1.83^{\mathrm{a}}$ & $1.68^{\mathrm{ab}}$ & $1.72^{\mathrm{ab}}$ & $1.54^{\mathrm{b}}$ & 0.04 \\
\hline Survival (\%) & 77.8 & 77.8 & 77.8 & 77.8 & 68.9 & 1.43 \\
\hline
\end{tabular}

FBPM, fermented mushroom by-product; Pooled SEM, pooled standard error of means; WG, weight gain; SGR, specific growth rate; FE, feed efficiency; PER, protein efficiency ratio; HSI, hepatosomatic index; SD, standard deviation.

${ }^{1} \mathrm{FBPM}_{0}: 100 \%$ fish meal-based diet; $\mathrm{FBPM}_{5}, \mathrm{FBPM}_{10}, \mathrm{FBPM}_{20}, \mathrm{FBPM}_{30}: 5 \%, 10 \%, 20 \%$, and $30 \%$ fish meal protein replaced by FBPM, respectively.

${ }^{2} \mathrm{SD} / \sqrt{n} \cdot{ }^{3} \mathrm{WG}(\%)=[($ final wt. - initial wt. $) /$ initial wt. $] \times 100 .{ }^{4} \mathrm{SGR}(\% / \mathrm{d})=\left[\left(\log _{\mathrm{e}}\right.\right.$ final wt. $-\log _{\mathrm{e}}$ initial wt. $\left.) / \mathrm{days}\right] \times 100$.

${ }^{5} \mathrm{FE}(\%)=($ wet weight gain/dry feed intake $) \times 100 .{ }^{6} \mathrm{PER}(\%)=$ wet wt. gain/protein intake. ${ }^{7} \mathrm{HSI}(\%)=($ wet liver wt. $/$ wet body wt. $) \times 100$.

Means of triplicate groups of fish where values in the same row with different superscripts are significantly different $(\mathrm{p}<0.05)$.

$25^{\circ} \mathrm{C}$ for $30 \mathrm{~min}$. The opsonized zymosan was separated by centrifugation, washed three times and suspended in HBSS. The reactive oxygen intermediates (ROIs) produced by stimulated phagocytes were quantified using an automatic photoluminometer (MPL2 model, Berthold Detection Systems, Hamburg, Germany). Each test cuvette contained $0.7 \mathrm{~mL}$ luminol (Sigma) made according to the method (Scott and Klesius, 1981), $0.4 \mathrm{~mL}$ cell suspension, and 0.3 $\mathrm{mL}$ opsonized zymosan, which was added just prior to measurements. Measurements were made for $100 \mathrm{~min}$ and the light emission was recorded as relative luminescence unit (RLU/s).

Lysozyme activity: Test serum $(0.1 \mathrm{~mL})$ was added to 2 $\mathrm{mL}$ of a suspension of Micrococcus lysodeikticus $(0.2$ $\mathrm{mg} / \mathrm{mL}$ ) in a $0.05 \mathrm{M}$ sodium phosphate buffer ( $\mathrm{pH}$ 6.2). The reactions were carried out at $20^{\circ} \mathrm{C}$ and absorbance at 530 $\mathrm{nm}$ was measured between $0.5 \mathrm{~min}$ and $4.5 \mathrm{~min}$ on a spectrophotometer. A lysozyme activity unit was defined as the amount of enzyme producing a decrease in absorbance of $0.001 / \mathrm{min}$ (Won et al., 2004).

\section{Statistical analysis}

All data were analyzed by one-way (Statistix 3.1, Analytical Software, St. Paul, MN, USA) to test for the effects of the dietary treatments. When a significant treatment effect was observed, a least significant difference test was used to compare means. Treatment effects were considered at $\mathrm{p}<0.05$ level of significance. Broken line model (Robinson Norton and Baker, 1979) was used to evaluate the maximal dietary level of fermented byproducts of mushroom as a FM replacer.

\section{RESULTS}

\section{Growth performance}

Growth performance of Amur catfish, Silurus asotus, fed different levels of dietary fermented mushroom by- product, Pleurotus ostreatus, as a FM replacer is shown in Table 2. The average WG of fish fed $\mathrm{FBPM}_{0}$ or $\mathrm{FBPM}_{5}$ were significantly higher than those of fish fed $\mathrm{FBPM}_{20}$ or FBPM $_{30} \quad(\mathrm{p}<0.05)$. However, there was no significant differences in WG among the fish fed $\mathrm{FBPM}_{0}, \mathrm{FBPM}_{5}$, or $\mathrm{FBPM}_{10}$, and between fish fed $\mathrm{FBPM}_{10}$ or $\mathrm{FBPM}_{20}$, and also between those fed $\mathrm{FBPM}_{20}$ or $\mathrm{FBPM}_{30}$. The SGR of fish fed $\mathrm{FBPM}_{0}, \mathrm{FBPM}_{5}, \mathrm{FBPM}_{10}$, or $\mathrm{FBPM}_{20}$ were significantly higher than that of fish fed $\mathrm{FBPM}_{30}$ diet $(\mathrm{p}<0.05)$. The FE and PER of fish fed $\mathrm{FBPM}_{0}$ or $\mathrm{FBPM}_{5}$ were significantly higher than that of fish fed $\mathrm{FBPM}_{30}(\mathrm{p}<0.05)$. The HSI of fish fed $\mathrm{FBPM}_{5}$ was significantly higher than that of fish fed $\mathrm{FBPM}_{30}(\mathrm{p}<0.05)$. However, there were no significant differences in SGR, FE, PER, or HSI among fish fed $\mathrm{FBPM}_{0}, \mathrm{FBPM}_{5}, \mathrm{FBPM}_{10}$, or FBPM 20 diets $(\mathrm{p}<0.05)$. Also, no significant differences were found in survival rate of fish fed any of the experimental diets $(\mathrm{p}<0.05)$. Broken line analysis of WG indicated that FBPM could replace $6.3 \%$ of FM without any adverse effects on growth performance of Amur catfish, Silurus asotus (Figure 1).

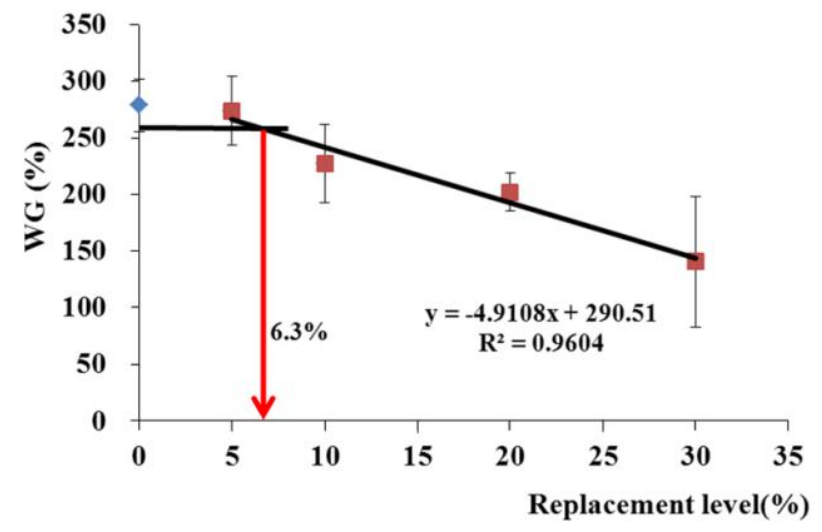

Figure 1. Broken line analysis on weight gain (WG, \%) of Amur catfish fed fermented by-product of mushroom (FBPM) as a fish meal (FM) replacer. Values of the X-axis are the FMPM levels in experimental diets. Values are means \pm SD of 3 replication. SD, standard deviation. 
Table 3. Whole-body proximate composition of juvenile Amur catfish, Silurus asotus, fed dietary fermented by-product of mushroom, Pleurotus ostreatus, as a fish meal replacer

\begin{tabular}{lcccccc}
\hline \multirow{2}{*}{ Items } & \multicolumn{5}{c}{ Diets $^{1}$} & \multirow{2}{*}{ Pooled SEM $^{2}$} \\
\cline { 2 - 5 } & $\mathrm{FBPM}_{0}$ & $\mathrm{FBPM}_{5}$ & $\mathrm{FBPM}_{10}$ & $\mathrm{FBPM}_{20}$ & $\mathrm{FBPM}_{30}$ & \\
\hline Moisture & $76.7^{\mathrm{b}}$ & $76.5^{\mathrm{b}}$ & $77.6^{\mathrm{b}}$ & $76.7^{\mathrm{b}}$ & $79.6^{\mathrm{a}}$ & 0.35 \\
Crude protein & $65.0^{\mathrm{c}}$ & $67.7^{\mathrm{b}}$ & $67.1^{\mathrm{b}}$ & $67.2^{\mathrm{b}}$ & $70.6^{\mathrm{a}}$ & 0.51 \\
Crude lipid & $21.8^{\mathrm{a}}$ & $20.5^{\mathrm{a}}$ & $19.7^{\mathrm{a}}$ & $20.2^{\mathrm{a}}$ & $14.6^{\mathrm{b}}$ & 0.71 \\
Ash & $11.9^{\mathrm{b}}$ & $11.5^{\mathrm{b}}$ & $12.1^{\mathrm{b}}$ & $12.8^{\mathrm{ab}}$ & $14.1^{\mathrm{a}}$ & 0.31 \\
\hline
\end{tabular}

FBPM, fermented mushroom by-product; Pooled SEM, pooled standard error of means.

${ }^{1} \mathrm{FBPM}_{0}: 100 \%$ fish meal-based diet; $\mathrm{FBPM}_{5}, \mathrm{FBPM}_{10}, \mathrm{FBPM}_{20}, \mathrm{FBPM}_{30}: 5 \%, 10 \%, 20 \%$, and $30 \%$ fish meal protein replaced by FBPM, respectively.

${ }^{2} \mathrm{SD} / \sqrt{n}$.

Means of triplicate groups of fish where values in the same row with different superscripts are significantly different $(\mathrm{p}<0.05)$.

\section{Whole body proximate composition}

Whole-body proximate composition of fish fed dietary FBPM, Pleurotus ostreatus, as a FM replacer is shown in Table 3. The crude protein content was significantly lower for the fish fed $\mathrm{FBPM}_{0}$ than those of fish fed any of the other experimental diets $(\mathrm{p}<0.05)$. However, there was no significant difference in crude protein content among the fish fed $\mathrm{FBPM}_{5}, \mathrm{FBPM}_{10}$, or $\mathrm{FBPM}_{20}$. Data for the moisture content showed, significantly higher moisture content for the fish fed $\mathrm{FBPM}_{30}$ than those of fish fed the other experimental diets $(p<0.05)$. However, there was no significant difference in moisture content among the fish fed $\mathrm{FBPM}_{0}, \mathrm{FBPM}_{5}, \mathrm{FBPM}_{10}$, or $\mathrm{FBPM}_{20}$. While, crude lipid content was found to be significantly lower for the fish fed $\mathrm{FBPM}_{30}$ than those of fish fed the other diets $(\mathrm{p}<0.05)$. However, there was no significant difference in crude lipid content among the fish fed $\mathrm{FBPM}_{0}, \mathrm{FBPM}_{5}, \mathrm{FBPM}_{10}$, or $\mathrm{FBPM}_{20}$ diets $(\mathrm{p}<0.05)$. The data for the whole body ash content showed significantly lower value for the fish fed $\mathrm{FBPM}_{0}, \mathrm{FBPM}_{5}$, or $\mathrm{FBPM}_{10}$ than that of fish fed $\mathrm{FBPM}_{30}$ $\operatorname{diet}(\mathrm{p}<0.05)$. However, there was no significant difference in ash content among the fish fed $\mathrm{FBPM}_{0}, \mathrm{FBPM}_{5}$, or FBPM $_{10}$ and between fish fed $\mathrm{FBPM}_{20}$ and $\mathrm{FBPM}_{30}$ diets.

\section{Serological characteristics}

Table 4 shows the serological characteristics of Amur catfish, Silurus asotus, fed dietary FBPM, Pleurotus ostreatus, as a FM replacer. Hematocrit of fish fed $\mathrm{FBPM}_{20}$ was significantly higher than that of fish fed $\mathrm{FBPM}_{30}$ $(p<0.05)$. There were no significant differences in this parameter among the fish fed $\mathrm{FBPM}_{0}, \mathrm{FBPM}_{5}, \mathrm{FBPM}_{10}$, or $\mathrm{FBPM}_{20}$ and also among those fed $\mathrm{FBPM}_{0}, \mathrm{FBPM}_{5}$, $\mathrm{FBPM}_{10}$, or $\mathrm{FBPM}_{30}$ diets $(\mathrm{p}<0.05)$. There were no significant differences in $\mathrm{Hb}$ or total protein of fish fed any of the experimental diets except for the $\mathrm{Hb}$ of fish fed $\mathrm{FBPM}_{5}$, which was significantly higher than those of fish fed $\mathrm{FBPM}_{0}, \mathrm{FBPM}_{10}$, or $\mathrm{FBPM}_{20}$ and the total protein of fish fed $\mathrm{FBPM}_{0}$, which was significantly higher than those of fish fed $\mathrm{FBPM}_{5}, \mathrm{FBPM}_{10}, \mathrm{FBPM}_{20}$, or $\mathrm{FBPM}_{30}$ diets $(p<0.05)$. Serum glucose of fish fed $\mathrm{FBPM}_{0}$ was significantly higher than those of fish fed $\mathrm{FBPM}_{5}, \mathrm{FBPM}_{10}$, $\mathrm{FBPM}_{20}$, or $\mathrm{FBPM}_{30}$. Also, serum glucose of fish fed $\mathrm{FBPM}_{0}, \mathrm{FBPM}_{5}$, or $\mathrm{FBPM}_{20}$ were significantly higher than that of fish fed $\mathrm{FBPM}_{30}$ diet $(\mathrm{p}<0.05)$. However, there was no significant differences in this parameter among fish fed $\mathrm{FBPM}_{5}, \mathrm{FBPM}_{10}$, or $\mathrm{FBPM}_{20}$ and also between those fed FBPM $_{10}$, or FBPM 30 diets $(\mathrm{p}<0.05)$.

\section{Nonspecific immunological responses}

Nonspecific immune response parameters of fish fed all the experimental diets are shown in Table 5. Lysozyme activity of fish fed $\mathrm{FBPM}_{0}$ or $\mathrm{FBPM}_{5}$ were significantly higher than those of fish fed $\mathrm{FBPM}_{10}, \mathrm{FBPM}_{20}$, or $\mathrm{FBPM}_{30}$ diets $(p<0.05)$. However, there was no significant differences in lysozyme activity between fish fed $\mathrm{FBPM}_{0}$ or $\mathrm{FBPM}_{5}$, and also among those fed $\mathrm{FBPM}_{10}, \mathrm{FBPM}_{20}$, or

Table 4. Serological characteristics of juvenile Amur catfish, Silurus asotus, fed dietary fermented by-product of mushroom, Pleurotus ostreatus, as a fish meal replacer

\begin{tabular}{|c|c|c|c|c|c|c|}
\hline & \multicolumn{5}{|c|}{ Diets $^{1}$} & \multirow{2}{*}{$\begin{array}{c}\text { Pooled } \\
\text { SEM }^{2}\end{array}$} \\
\hline & $\mathrm{FBPM}_{0}$ & $\mathrm{FBPM}_{5}$ & $\mathrm{FBPM}_{10}$ & $\mathrm{FBPM}_{20}$ & $\mathrm{FBPM}_{30}$ & \\
\hline $\mathrm{PCV}^{3}$ & $24.1^{\mathrm{ab}}$ & $24.9^{\mathrm{ab}}$ & $25.7^{\mathrm{ab}}$ & $26.9^{\mathrm{a}}$ & $22.4^{\mathrm{b}}$ & 0.61 \\
\hline $\mathrm{Hb}(\mathrm{g} / 100 \mathrm{~mL})$ & $14.7^{\mathrm{b}}$ & $18.4^{\mathrm{a}}$ & $15.2^{\mathrm{b}}$ & $14.6^{\mathrm{b}}$ & $16.1^{\mathrm{ab}}$ & 0.53 \\
\hline Total protein $(\mathrm{g} / \mathrm{dL})$ & $3.1^{\mathrm{a}}$ & $2.7^{\mathrm{b}}$ & $2.7^{\mathrm{b}}$ & $2.8^{\mathrm{b}}$ & $2.6^{\mathrm{b}}$ & 0.05 \\
\hline Glucose (mg/dL) & $76.3^{\mathrm{a}}$ & $73.7^{\mathrm{b}}$ & $69.0^{\mathrm{bc}}$ & $69.7^{\mathrm{b}}$ & $64.3^{\mathrm{c}}$ & 1.5 \\
\hline
\end{tabular}

FBPM, fermented mushroom by-product; Pooled SEM, pooled standard error of means; PCV, packed cell volume; Hb, hemoglobin.

${ }^{1} \mathrm{FBPM}_{0}: 100 \%$ fish meal-based diet; $\mathrm{FBPM}_{5}, \mathrm{FBPM}_{10}, \mathrm{FBPM}_{20}, \mathrm{FBPM}_{30}: 5 \%, 10 \%, 20 \%$, and $30 \%$ fish meal protein replaced by FBPM, respectively.

${ }^{2} \mathrm{SD} / \sqrt{n} \cdot{ }^{3}$ Hematocrit $(\%)$.

Means of triplicate groups of fish where values in the same row with different superscripts are significantly different $(\mathrm{p}<0.05)$. 
Table 5. Nonspecific immune responses of juvenile Amur catfish, Silurus asotus, fed dietary fermented by-product of mushroom, Pleurotus ostreatus, as a fish meal replacer

\begin{tabular}{|c|c|c|c|c|c|c|}
\hline & \multicolumn{5}{|c|}{ Diets $^{1}$} & \multirow{2}{*}{$\begin{array}{l}\text { Pooled } \\
\text { SEM }^{2}\end{array}$} \\
\hline & $\mathrm{FBPM}_{0}$ & $\mathrm{FBPM}_{5}$ & $\mathrm{FBPM}_{10}$ & $\mathrm{FBPM}_{20}$ & $\mathrm{FBPM}_{30}$ & \\
\hline Lysozyme activity (U/mL) & $72.1^{\mathrm{a}}$ & $69.2^{\mathrm{a}}$ & $60.5^{\mathrm{b}}$ & $56.4^{\mathrm{b}}$ & $54.6^{\mathrm{b}}$ & 1.43 \\
\hline CL (RLU/s) & $42,324^{\mathrm{c}}$ & $78,435^{\mathrm{a}}$ & $71,839^{\mathrm{ab}}$ & $63,304^{\mathrm{b}}$ & $39,868^{\mathrm{c}}$ & 4,137 \\
\hline
\end{tabular}

FBPM, fermented mushroom by-product; Pooled SEM, pooled standard error of means; CL, chemiluminescent responses.

${ }^{1} \mathrm{FBPM}_{0}: 100 \%$ fish meal-based diet; FBPM $, \mathrm{FBPM}_{10}, \mathrm{FBPM}_{20}, \mathrm{FBPM}_{30}: 5 \%, 10 \%$, 20\%, and 30\% fish meal protein replaced by FBPM, respectively.

${ }^{2} \mathrm{SD} / \sqrt{n}$.

Means of triplicate groups of fish where values in the same row with different superscripts are significantly different $(\mathrm{p}<0.05)$

$\mathrm{FBPM}_{30}$ diets $(\mathrm{p}<0.05)$. The chemiluminescent $(\mathrm{CL})$ response of fish fed $\mathrm{FBPM}_{5}$ was significantly higher than those of fish fed $\mathrm{FBPM}_{0}, \mathrm{FBPM}_{20}$, or $\mathrm{FBPM}_{30}$ diets $(\mathrm{p}<0.05)$. Furthermore, CL of fish fed $\mathrm{FBPM}_{5}, \mathrm{FBPM}_{10}$, or FBPM 20 were significantly higher than those of fish fed $\mathrm{FBPM}_{0}$, or $\mathrm{FBPM}_{30}$ diets $(\mathrm{p}<0.05)$. There were no significant differences in CL between fish fed $\mathrm{FBPM}_{0}$ or $\mathrm{FBPM}_{30}$, and between fish fed $\mathrm{FBPM}_{5}$ or $\mathrm{FBPM}_{10}$ and also between fish fed $\mathrm{FBPM}_{10}$, or $\mathrm{FBPM}_{20}$ diets $(\mathrm{p}<0.05)$.

\section{DISCUSSION}

Growing ecological and economical concern associated with the use of FM has exerted pressure on nutritionists to evaluate viable alternative protein sources to FM in aquafeed. Consequently, numerous studies have been done on replacement of FM in fish feed with plant protein sources such as soybean meal and other soy protein products (Mcgoogan and Gatlin, 1997; Day and Gonzalez, 2000; Choi et al., 2004; Lim et al., 2004; Sun et al., 2007; Kim et al., 2008). Animal protein sources such as feather meal, $\mathrm{Hb}$ powder, and meat and bone meal have equally been researched on as replacers for FM in fish feed (Bishop et al., 1995; Hasan et al., 1997; Lee and Bai, 1997a,b; Bureau et al., 2000). Although by-products of mushroom, Pleurotus ostreatus, have been used in ruminant feed (Adamovic et al., 1998; Silvana et al., 2006; Song et al., 2007; Oh et al., 2010; Kim et al., 2011), information on the use of these ingredients in fish feed is scarce. The present investigation showed that fermented mushroom, Pleurotus ostreatus, by-product can be used as a dietary FM replacer in juvenile Amur catfish, Silurus asotus.

Although WG, SGR, FE and PER decreased with FBPM supplementation, no significant differences were recorded in these parameters between fish fed the FBPM free diets and those fed diets supplemented with 5\% and 10\% FBPM $(\mathrm{p}<0.05)$. Since little information is available on FM replacement in Amur catfish and on the use of FBPM as a FM replacer in fish, it is difficult to conclusively state the cause of the reduction in growth performance of fish in this trial. However, FM replacement studies in other species using various plant and animal protein sources suggest that
FM could be successfully replaced by these alternative protein sources up to certain levels without any adverse effects on growth performance/nutrient utilization but beyond such levels, growth/nutrient utilization could be impaired (Alexis et al., 1985; Brown et al., 1985; Shimizu et al., 1990; Hughes, 1993; McGoogan and Gatlin, 1997; Abdel-Warith et al., 2001; Lim et al., 2004). Abdel-Warith et al. (2001) recorded good growth of Clarias gariepinus up to $40 \%$ replacement of FM with PBM but noted depression in growth and abnormality in histological structure of fish with increasing levels of PBM in diets. Similarly, Sun et al. (2007) recorded an optimum replacement level of $30 \%$ of FM with fermented fisheries by-products and soybean curd residues mixture. Some of the suggested causes of a reduction in performance above a certain level of replacement in these studies include variations in protein content, amino acid profiles and digestibility, as well as the presence of some antinutritional factors and palatability depressants (Lim et al., 2004; Fasakin et al., 2005; Sun et al., 2007).

Studies in ruminants indicate that certain levels of various mushroom by-products can be included in the animal feed to replace other forage sources. Oh et al. (2010) reported that Pleurotus eryngii and Pleurotus osteratus could be used to replace $40 \%$ of rice straw without any severe negative metabolic effects in Hanwoo steers. Xu et al. (2010) suggested that timothy hay can be replaced by $6.5 \%$ of spent mushroom substrate in a silage-based total mixed ration for wethers. Similar to the practice in ruminant nutrition, our results suggest that FBPM can be effectively incorporated in fish feed, replacing $6.3 \%$ of FM, the major ingredient in aquafeed.

Whole-body proximate composition of fish was not seriously affected by FBPM inclusion as a FM replacer in the diets $(\mathrm{p}<0.05)$. No significant differences were recorded by Lim et al. (2004) in whole-body proximate composition of growing rockfish, Sebastes schlegeli, fed dehulled soybean meal as a FM replacer. Furthermore, although significant differences were found in whole-body proximate composition of juvenile rockfish by the same authors, no clear trends were observed. Also, no clear trends were found in whole-body proximate composition of juvenile 
olive flounder, Paralichthys olivaceus, fed fermented fisheries by-products and soybean curd residues mixture as a FM replacer (Sun et al., 2007).

Although significant differences were recorded in serological parameters of Amur catfish fed FBPM as a FM replacer, no clear trends were found. Only serum total protein and glucose of fish fed $\mathrm{FBPM}_{0}$ were significantly higher than those of fish fed other diets while rest of the parameters fluctuated among the different treatments $(p<0.05)$. Serological characteristics can be used as an index of health status of fish (Blaxhall, 1972). Serological changes have been detected following different types of stress conditions like exposure to pollutants, diseases, hypoxia, etc. (Duthie and Tort, 1985). Hence, it could be suggested that any unhealthy condition caused by poor nutrition could affect the serological characteristics of fish. However, results in the present experiment do not indicate any observable adverse effects of FM replacement with FBPM, suggesting that FM replacement by FBPM does not adversely affect the serological characteristics of Amur catfish. Even the significantly high serum protein and glucose levels in fish fed $\mathrm{FBPM}_{0}$ do not conform to the trend in growth performance of fish in the present experiment. This may suggest serological parameters may not be greatly affected by FBPM inclusion. Similar to our findings, although growth performance was significantly affected by $\beta-1,3$ glucan and feed stimulants inclusion in olive flounder feed, out of the six serological parameters tested only HCT and serum glutamic oxaloacetic transaminase were significantly different among treatments (Yoo et al., 2007).

Lysozyme activity and CL response have been frequently used as indicators of nonspecific immune functions, which are of primary importance in combating infections in fish (Vazzana et al., 2003; Saurabh and Sahoo, 2008). During phagocytosis, phagocytic cells increase their oxygen consumption and ROIs are produced in a process called the respiratory burst (Secombes, 1994). The CL response measures the photon emission resulting from the ROIs formation. Lysozyme, a mucolytic enzyme of leucocitic origin, is an important defense molecule of the innate immune system, which is important in mediating protection against microbial invasion (Saurabh and Sahoo, 2008). Increased lysozyme activity and CL response are indications of improved immunity responses in fish (Panigrahi et al., 2004; Kim and Austin, 2006; Taoka et al., 2006). Lysozyme activity of fish decreased with FBPM levels in diets. However, no significant differences were found between fish fed FBPM 0 and those fed FBPM , while $C L$ response actually increased and then decreased after the FBPM inclusion level of $5 \%(p<0.05)$. These results show that immune responses of fish were not adversely affected due to FM replacement by FBPM up to $5 \%$. However, as these two parameters had their peaks at two different inclusion levels, it is difficult to determine the inclusion level of FBPM which actually improved the nonspecific immune responses of Amur catfish in this trial.

However, the present experiment opens a new avenue to evaluate the optimum level of dietary FBPM as a FM replacer with supplemental phytase and amino acids viz. methionine and lysine. In conclusion, based upon the broken line regression analysis of WG the maximal dietary inclusion level for FBPM as a FM replacer could be $6.3 \%$ without any adverse effects on whole body composition and on serological characteristics in Amur catfish.

\section{ACKNOWLEDGMENTS}

This experiment was supported by Feeds \& Foods Nutrition Research Center at Pukyong National University.

\section{REFERENCES}

Abdel-Warith, A., P. M. Russell, and S. J. Davies. 2001. Inclusion of a commercial poultry by-product meal as a protein replacement of fish meal in practical diets for the African catfish, Clarias gariepinus. Aquac. Res. 32:296-305.

Adamovic, M., G. Grubic, I. Milenkovic, R. Jovanovic, R. Protic, L. Stretenovic, and L. Stoicevic. 1998. The biodegradation of wheat straw by Pleurotus ostreatus mushrooms and its use in cattle feeding. Anim. Feed Sci. Technol. 71:357-362.

Alexis, M. N., E. Paraparaskewa, and V. Theochari. 1985. Formulation of practical diets for rainbow trout (Salmo gairdneri) made by partial or complete substitution of fish meal by poultry by-products and certain plant by-products. Aquaculture 50:61-73.

AOAC. 1995. Official Methods of Analysis. 16th ed. Association of Official Analytical Chemists. Arlington, Virginia, USA.

Bai, S. C. and K. W. Kim. 1997. Effects of dietary animal protein sources on growth and body composition in Korean rockfish, Sebastes schlegeli. J. Aquac. 10:77-85 (in Korean with English Abstr).

Bai, S. C., H. K. Jang, and E. S. Cho. 1998. Possible use of the animal by-product mixture as a dietary fish meal replacer in growing common carp (Cyprinus carpio). J. Korean Fish. Soc. 31:380-385.

Bai, S. C., H. K. Jang, and K. H. Kim. 1997. Evaluation of feather meal and meat and bone meal as the fish meal replacer in Israeli carp diets. J. Aquac. 10:153-161.

Banik, S. and R. Nandi. 2004. Effect of supplementation of rice straw with biogas residual slurry manure on the yield, protein and mineral contents of oyster mushroom. Ind. Crops Prod. 20: 311-319.

Bishop, C. D., R. A. Angus, and S. A. Watts. 1995. The use of feather meal as a replacement for fish meal in the diet of Oreochromis niloticus fry. Bioresour. Technol. 54:291-295.

Blaxhall, P. C. 1972. The haematological assessment of the health of freshwater fish. J. Fish Biol. 4:593-604. 
Brown, B. A. 1980. Routine hematology procedure. Hematology: Principles and Procedures. Lea and Febiger, Philadelphia, PA, USA. pp. 71-112.

Brown, P. B., R. J. Strange, and K. R. Robbins. 1985. Protein digestibility coefficients for yearling channel catfish fed high protein feedstuffs. Prog. Fish Cult. 47:94-97.

Bureau, D. P., A. M. Harris, D. J. Bevan, L. A. Simmons, P. A. Azevedo, and C. Y. Cho. 2000. Feather meals and meat and bone meals from different origins as protein sources in rainbow trout, Oncorhynchus mykiss, diets. Aquaculture 181: 281-291.

Carter, C. G. and R. C. Hauler. 2000. Fish meal replacement by plant meals in extruded feeds for Atlantic salmon, Salmo salar L. Aquaculture 185:299-311.

Chang, S. T. 1999. World production of cultivated and medicinal mushrooms in 1997 with emphasis on Lentinus edodes (Berk) Sing, in China. Int. J. Med. Mushrooms 1:291-300.

Choi, S. M., X. J. Wang, G. J. Park, S. R. Lim, K. W. Kim, S. C. Bai, and I. S. Shin. 2004. Dietary dehulled soybean meal as a replacement for fish meal in fingerling and growing olive flounder, Paralichthys olivaceus (Temminck et Schlegel). Aquac. Res. 35:410-418.

Day, O. J. and H. G. Plascencia Gonzalez. 2000. Soybean protein concentrate as a protein source for turbot, Scophthalmus maximus L. Aquac. Nutr. 6:221-228.

Duthie, G. G. and L. Tort. 1985. Effect of dorsal aortic cannulatton on the respiration and haematology of the Mediterranean dog fish, Scyllorhlnus canlcula L. Comp. Biochem. Physlol. A Physlol. 81A:879-883.

FAO. 2012. FISHSTAT Plus, universal software for fishery statistical time series. Food and Agriculture Organization, United Nations, Rome. Electronic webpage.

Fasakin, E. A., R. D. Serwata, and S. J. Davies. 2005. Comparative utilization of rendered animal derived products with or without composite mixture of soybean meal in hybrid tilapia (Oreochromis niloticus $\times$ Oreochromis mossambicus) diets. Aquaculture 249:329-338.

Gordon, M., B. Bihari, E. Goosby, R. Gorter, M. Greco, M. Guralnik, T. Mimura, V. Rudinicki, R. Wong, and Y. Kaneko. 1998. A placebocontrolled trial of the immune modulator, lentinan, in HIV-positive patients: A phase I/II trial. J. Med. 29:305-330.

Hasan, M. R., M. S. Haq, P. M. Das, and G. Mowlah. 1997. Evaluation of poultry-feather meal as a dietary protein source for Indian major carp, Labeo rohita, fry. Aquaculture 151:4754.

Hughes, S. G. 1993. Single-feeding response of chinook salmon fry to potential feed intake modifiers. Prog. Fish Cult. 55:4042.

Kader, M. A., S. Koshio, M. Ishikawa, S. Yokoyama, and M. Bulbul. 2010. Supplemental effects of some crude ingredients in improving nutritive values of low fishmeal diets for red sea bream, Pagrus major. Aquaculture 308:136-144.

Kim, D. H. and B. Austin. 2006. Innate immune responses in rainbow trout (Oncorhynchus mykiss Walbaum) induced by probiotics. Fish Shellish Immunol. 21:513-524.

Kim, M. K., H. G. Lee, J. A. Park, S. K. Kang, and Y. J. Choi. 2011. Recycling of fermented sawdust-based oyster mushroom spent substrate as a feed supplement for postweaning calves. Asian
Australas. J. Anim. Sci. 24:493-499.

Kim, Y. C., G. Y. Yoo, X. J. Wang, S. H. Lee, I. S. Shin, and S. C. Bai. 2008. Long term feeding effects of dietary dehulled soybean meal as a fish meal replacer in growing olive flounder, Paralichthys olivaceus. Asian Australas. J. Anim. Sci. 21:868872.

Lakhanpal, T. N. and M. Rana. 2005. Medicinal and nutraceutical genetic resources of mushrooms. Plant Genet. Resour.: Characterization and utilization 3:288-303.

Lee, K. J. and S. C. Bai. 1997a. Haemoglobin powder as a dietary fish meal replacer in juvenile Japanese eel, Anguilla japonica (Temminck et Schlegel). Aquac. Res. 28:509-516.

Lee, K. J. and S. C. Bai. 1997b. Hemoglobin powder as a dietary animal protein source for juvenile Nile tilapia. Prog. Fish-Cult. 59:266-271.

Lim, S. R., S. M. Choi, X. J. Wang, K. W. Kim, I. S. Shin, T. S. Min, and S. C. Bai. 2004. Effects of dehulled soybean meal as a fish meal replacer in diets for fingerling and growing Korean rockfish, Sebastes schlegeli. Aquaculture 231:457-468.

McGoogan, B. B. and M. D. Gatlin III. 1997. Effects of replacing fish meal with soybean meal in diets for red drum, sciaenops ocellatus, and potential for palatability enhancement. J. World Aquac. Soc. 28:374-385.

Naylor, L. R., W. R. Hardy, P. D. Bureau, A. Chiu, M. Elliott, P. A. Farrell, I. Forster, M. D. Gatlin, J. R. Goldburg, K. Hua, and D. P. Nichols. 2009. Feeding aquaculture in an era of finite resources. Proc. Natl. Acad. Sci. USA. 106:15103-15110

Oh, Y. K., W. M. Lee, C. W. Choi, K. H. Kim, S. K. Hong, S. C. Lee, Y. J. Seol, W. S. Kwak, and N. J. Choi. 2010. Effects of spent mushroom substrates supplementation on rumen fermentation and blood metabolites in Hanwoo steers. Asian Australas. J. Anim. Sci. 23:1608-1613.

Panigrahi, A., V. Kiron, T. Kobayashi, J. Puangkaew, S. Satoh, and H. Sugita. 2004. Immune responses in rainbow trout, Oncorhynchus mykiss, induced by a potential probiotic bacteria Lactobacillus rhamnosus JCM1136. Vet. Immunol. Immunopathol. 102:379-388.

Refstie, S., T. Storebakken, G. Baeverfjord, and A. Roem. 2001. Long-term protein and lipid growth of Atlantic salmon (Salmo salar) fed diets with partial replacement of fish meal by soy protein products at medium or high lipid levels. Aquaculture 193:91-106.

Royse, D. J. 2002. Influence of spawn rate and commercial delayed release nutrient levels on Pleurotus cornucopiae (oyster mushroom) yield, size and time to production. Appl. Microbiol. Biotechnol. 58:527-531.

Saurabh, S. and P. K. Sahoo. 2008. Lysozyme: an important defence molecule of fish innate immune system. Aquac. Res. 39:223-239.

Scott, A. L., P. H. Klesius. 1981. Chemiluminescence: a novel analysis of phagocytosis in fish. Dev. Biol. Stand. 49:243-254.

Secombes, C. J. 1994. Macrophage activation in fish. Modulators of Fish Immune Responses 1:49-57.

Shimizu, C., A. Ibrahim, T. Tokoro, and Y. Shirakawa. 1990. Feeding stimulation in sea bream, Pagrus major, fed diets supplemented with Antarctic krill meals. Aquaculture 89:43-53. Silvana, A., M. J. Pianzzola, M. Soubes, and M. P. Cerdeiras. 2006. Biodegradation of agroindustrial wastes by Pleurotus spp. for its use as ruminant feed. Electron. J. Biotechnol. 9:215-220. 
Sonck, E., E. Stuyven, B. Goddeeris, and E. Cox. 2010. The effect of beta-glucans on porcine leukocytes. Vet. Immunol. Immunopathol. 135:199-207.

Song, Y. M., S. D. Lee, R. Chowdappa, H. Y. Kim, S. K. Jin, and I. S. Kim. 2007. Effects of fermented oyster mushroom (Pleurotus ostreats) by-product supplementation on growth performance, blood parameters and meat quality in finishing berkshire pigs. Animal 1:301-307.

Suarez, J. A., C. Tudela, D. Davis, Z. Daugherty, M. Taynor, L. Glass, R. Hoenig, A. Buentello, and D. D. Beenetti. 2013. Replacement of fish meal by a novel non-GM variety of soybean meal in cobia, Rachycentron canadum: Ingredient nutrient digestibility and growth performance. Aquaculture 416-417:328-333.

Sun, M. H., Y. C. Kim, O. E. Okorie, S. Devnath, G. Y. Yoo, S. H. Lee, Y. K. Jo, and S. C. Bai. 2007. Use of fermented fisheries by-products and soybean curd residues mixture as a fish meal replacer in diets of juvenile olive flounder, Paralichthys olivaceus. J. World Aquac. Soc. 38:543-549.
Vazzana, M., D. Parrinello, and M. Cammarata. 2003. Chemiluminescence response of $\beta$-glucan stimulated leukocytes isolated from different tissues and peritoneal cavity of Dicentrarchus labrax. Fish Shellfish. Immunol. 14:423-434.

Wasser, S. P. and A. L. Weis. 1999. Therapeutic effects of substances occurring in higher Basidiomycetes mushrooms: A modern perspective. Crit. Rev. Immunol. 19:65-96.

Won, K. M., S. M. Kim, and S. I. Park. 2004. The effects of $\beta-1$, 3/1, 6-linked glucan in the diet on immune responses of olive flounder, Paralichthys olivaceus by oral administration. J. Fish Pathol. 17:29-38 (written in Korean with English abstract).

World Bank Commodity. 2010. Commodity price data of the World Bank. Washington DC, USA. Electronic webpage.

Xu, C., Y. Cai, J. Zhang, and H. Matsuyama. 2010. Feeding value of total mixed ration silage with spent mushroom substrate. Anim. Sci. J. 81:194-198.

Yoo, G. Y., S. H. Lee, Y. C. Kim, O. E. Okorie, G. J. Park, Y. O. Han, S. M. Choi, J. C. Kang, M. H. Sun, and S. C. Bai. 2007. Effects of dietary $\beta-1,3$ glucan and feed stimulants in juvenile olive flounder, Paralichthys olivaceus. J. World Aquac. Soc. $38: 138-145$. 